\title{
Aspectos sobre desenvolvimento de linguagem oral em craniossinostoses sindrômicas $* * * *$
}

\section{Developmental aspects of oral language in craniosynostosis}

\author{
Ana Paula Arduino-Meirelles* \\ Cristina Broglia Feitosa de Lacerda** \\ Vera Lúcia Gil-da-Silva-Lopes***
}

*Fonoaudióloga. Mestre em Saúde da Criança e do Adolescente - Faculdade de Ciências Médicas - Universidade Estadual de Campinas. Endereço para correspondência: Rua Doutor Teodoro Langaard, 840 apto 34, Bonfim -

Campinas - SP - CEP 13070-060

(aparduino@bol.com.br)

**Fonoaudióloga. Pós-Doutorado pelo Istituto di Scienze e Tecnologie della Cognizione (ISTC - Roma). Docente do Curso de Fonoaudiologia da Universidade Metodista de Piracicaba.

***Médica. Livre-Docente em Genética Clínica. Professor Associado do Departamento de Genética Médica Faculdade de Ciências Médicas Universidade Estadual de Campinas.

*****Trabalho Elaborado e Desenvolvido no Departamento de Genética Médica da Faculdade de Ciências Médicas da Universidade Estadual de Campinas.

Revisão de Literatura

Artigo Submetido a Avaliação por Pares

Conflito de Interesse: não

Recebido em 30.11.2004.

Revisado em 02.03.2005; 01.12.2005 04.06.2006; 11.05.2006; 06.07.2006. Aceito para publicação em 06.07.2006.

\begin{abstract}
Background: aspects of language development in craniosynostosis. Craniosynostosis (premature fusion of the cranial sutures) has an incidence of 0.4 to $1 / 1.000$ newborns. Etiology for this congenital anomaly includes environmental and genetic factors. Regarding the form of presentation, it can occur in its isolated form or associated to other congenital anomalies. For this last group, acrocephalosyndactilies are observed. These are genetically determined conditions which present phenotypic similarity, including the following syndromes: Saethre-Chotzen, Apert, Crouzon e Pfeiffer. As all of these conditions affect the craniofacial development, it is possible to find anatomic and functional interferences which determine language delays and/or deficits. Aim: to revise the literature concerning aspects related to normal verbal language development and to describe the main characteristics associated to this condition in children who present Apert, Crouzon, Pfeiffer and SaethreChotzen syndromes. A systematic review on syndromic craniosynostosis and oral language was performed, consulting Medline, Lilacs and other important references on this theme. Conclusion: several manifestations related to hearing and language have been detected in individuals with syndromic craniosynostosis. The most important are alterations in the sound conduction system, leading to hearing losses, and consequently interfering in language acquisition and development. For this reason, speech-language diagnosis and early intervention are recommended in order to eliminate or minimize damages in language acquisition and development.
\end{abstract}

Key Words: Craniosynostosis; Language Development; Genetics; Speech-Language and Hearing Sciences.

\section{Resumo}

Tema: aspectos sobre o desenvolvimento de linguagem oral em craniossinostoses sindrômicas. As craniossinostoses (fusão precoce das suturas cranianas) apresentam incidência em torno de 0,4 a 1/1.000 nativivos. Estas podem ocorrer devido a fatores ambientais ou genéticos. Com relação à forma de apresentação, estas podem ocorrer de maneira isolada ou associada a outros defeitos congênitos. Neste último grupo, destacam-se as acrocefalossindactilias, condições geneticamente determinadas, que apresentam similaridade fenotípica, sendo estas as síndromes de Saethre-Chotzen, Apert, Crouzon e Pfeiffer. Diante destas condições complexas que envolvem o arcabouço craniofacial, é possível encontrar interferências anatômicas e funcionais que determinem atrasos e/ou desvios de linguagem. Objetivo: revisar a literatura acerca dos aspectos fonoaudiológicos relacionados ao desenvolvimento normal da linguagem oral e descrever as principais características associadas a ela apresentadas por crianças com síndromes de Apert, Crouzon, Pfeiffer e Saethre-Chotzen. Foi realizada revisão sistemática de estudos sobre as craniossinostoses sindrômicas e dados referentes a linguagem oral nestes casos. Para isso, utilizou-se pesquisa na base de dados Medline e Lilacs, assim como outras publicações importantes para a conclusão do artigo. Conclusão: diversas manifestações relacionadas à audição e linguagem podem estar presentes em craniossinostoses sindrômicas. Destacam-se as alterações do sistema de condução do som, levando à perda auditiva, o que conseqüentemente prejudica a aquisição e desenvolvimento pleno da linguagem. Deste modo, recomenda-se o diagnóstico e tratamento fonoaudiológico adequados e precoces, eliminando ou minimizando os prejuízos para a aquisição e desenvolvimento da linguagem oral.

Palavras-Chave: Craniossinostose; Desenvolvimento da Linguagem; Genética, Fonoaudiologia.

Referenciar este material como:

ARDUINO-MEIRELLES, A. P.; LACERDA, C. B. F.; GIL-DA-SILVA-LOPES, V.L. Developmental aspects of oral language in craniosynostosis (original title:

3 Aspectos sobre desenvolvimento de linguagem oral em craniossinostoses sindrômicas. Pró-Fono Revista de Atualização Científica, Barueri (SP), v. 18, n. 2, p. 213220, maio-ago. 2006. 


\section{Introduction}

In general, craniosynostosis presents a prevalence of 0.4 to $1 / 1000$ individuals and may be defined as premature closure of one or more cranial sutures, resulting in an abnormally shaped skull and various side effects such as cranial hypertension, reduced cerebral blood flow, airway obstruction, reduced visual and hearing acuity, learning deficit and psychological disorders (Gorlin et al, 1990; Alonso, 1997; Cohen e Gorlin, 1997; Cohen and Maclean, 2000; Lee et al, 2002). The mechanism of cranial suture formation is a process that is balanced by proteins that stimulate and inhibit the growth process. Modulation of their expression results in the harmonious development of the calvaria (Oppermann, 2000).

Craniosynostosis, however, occurs as a result of an imbalance of factors involved in the regulation of proliferation, differentiation and apoptosis of cranial suture cells. Therefore, genetic and nongenetic factors may contribute to the failure of the suture tissue in exercing its proliferation and antidifferentiation functions (Wilkie, 1997).

The final shape of the cranium depends on wich sutures are affected, the number of sutures involved and the precise moment of fusion. Depending or the manifestas which cause the scaphocephaly (sagittal synostosis), brachycephaly (bicoronal synostosis), trigonocephaly (metopic synostosis), plagiocephaly (unilateral coronal synostosis) and oxycephaly - a cloverleaf skull or kleeblattschädel (fusion of multiple sutures) (Alonso, 1997; Cohen et al, 1997).

According to the anomaly observed, craniosynostosis may be classified as associated or isolated, being the late more frequent. Isolated craniosynostosis can be due to environmental factors (mechanical or teratogenic) such as the use during pregnancy of sodium valproate, retinoic acid and oxymetazoline and genetic factors related to eithora multi-factorial etiology or a monogenic inheritance (Cohen and Maclean, 2000). In these cases there are few reports on the detection of molecular alterations (Kan et al., 2002). There also doesn't seem to be any ethno-geographic preference and its occurrence is generally sporadic (Cohen and Maclean, 2000).

When it is familial, the most common inheritance is the autossomal dominant with a wide range of phenotypical expression and high degre of penetration. Sagittal synostosis accoursin $57 \%$ of the cases and is predominant in males, while coronal compromise is observed in $18-29 \%$ of the cases being slightly predominant among females. The metopic and lamboid sutures as well as the compromise of multiple sutures are less common events (Gorlin et al., 1990; Alonso, 1997; Cohen et al., 1997).

The anomalies in the upper and lower limbs, ears and cardiovascular system are the most common findings in associated craniosynostosis. In addition, mental deficiencies are also frequent. It is not rare that these findings compose syndromes with defined nosology and etiology (Alonso, 1997; Cohen et al., 1997, Cohen and Maclean, 2000).

Anomalies of the limbs known as Acrocephalossyndactylias (from Greek akros = tip, kefalos $=$ cranium, syn $=$ reunion, dactylo $=$ finger $)$ are outstanding among the craniosynostosis associated multiple anomalies. They constitute a group of congenital defects caracterized by similarity phenotype presenting craniosynostosis, ocular hypertelorism, prominent nose, hooked nose, mid-facial underdevelopment and variable anomalies of the hands and feet.

More common conditions may be included in this group such as Saethre-Chotzen Syndrome (Omim 101400), wich incidence is estimated in 1:25.000 to 1:50.000 live births, Apert Syndrome (Omim 101200), Pfeiffer Syndrome (Omim 101600) and Crouzon syndrome (Omim 123500) each one with an incidence of approximately 1: 100.000 as well as other rare conditions (Cohen and Maclean, 2000). In general, these clinical conditions are autosomal dominant .

Mutations in five genes (FGFR1, FGFR2, FGFR3, TWIST and MSX2) have been associated more often with syndromic craniosynostosis. Moreover, the similarity between the presentation of the different clinical conditions and the interrelationship among the various genetic factors reveals a common molecular regulatory pathway that is not needs completely understood (Bellus et al., 1996; Reardon et al., 1997; Robin, 1999; Passos-Bueno et al., 1999; Rice et al., 2000).

Since clinical conditions such as these are very complex and apparently unfavorable, it is resnable to consider that delays or deviations of language will occur. There for the purpose of this study is to review the main types of syndromic craniosynostoses that may interfere in the natural process of oral language acquisition and development. 
Oral Language Acquisition

Language is an example of higher cortical function and its development is sustained by a genetically defined anatomo-functional structure and by verbal stimulus that depends on the environment (Castaño, 2003).

One of the most distinctive characteristics of human life is communication (Andrade, 1997; Largo et al., 2003). The capacity of communication is a result of a complex integration of several biological systems (cerebral, auditory, motor, respiratory, digestive and others) which are inter-related with psychic and social aspects (Andrade, 1997).

Some studies indicate that an individual begins to discerni sounds related to the mother tongue or other languages even before birth, suggesting that of language acquisition intiates in intra-uterine lite (Nogueira et al., 2000; Cervera and Ygual, 2003).

Language acquisition means the learning of producing and using significancy with progressive adjustment of morphology to conventional rules (Luque and Vila, 1995). Therefore, both development and appropriation of language are processes that are also intimately related to social activities.

Speech, which is an activity that involves the use of oral language through words has to be common for every individual in a community so that everyone can be understood. Studies reveal that the vocabulary acquisition by a child is directly related to oral stimulation by the family and the individuals around (Mogford and Bishop, 2002).

Approximatily by eighteen months old a child can speak around 24 words. The vocabulary improves greatly during the next 2 years of life and consists of approximately two hundred to three hundred words (Altmann et al., 1997).

It should be kept in mind that every child has an individual rhythm, which varies according to several factors such as personality, stimulus, psychological and organic aspects and others. Moreover, total development of oral language does not depend only on the amount but also on the quality of stimuli offered to the child (Altmann et al., 1997).

There is a great variation on the rhythm of speech development from child to child, but the phonemic and phonologic systems in children with normal hearing are expected to be totally developed and well established by the age of four years (Andrade, 1997).
Factors that influence the acquisition and development of oral language

Language is one of the most complex skills that a human being can develop and its learning is continuos over a lifetime. It can also be linked to a series of other developmental aspects such as organic aspects (particularly the integrity of the central nervous system), sensorial and perceptual aspects (especially hearing), social, affective and cognitive conditions. Many factors that are among the main pathological factors related to language disorders such as neuromotor, sensorial, perceptive, emotional and social as well as cognitive disorders can hamper its natural development (Zorzi, 2003). Moreover, the etiology of language disorders often involves an interrelation between all these factors (Schimer et al., 2004).

Language alteration is one of the most common developmental problems and affects $3 \%$ to $15 \%$ of the children (Caputte and Accardo, 1991). It may even be associated with organic causes such as congenital diseases, specitically the craniosynostosis, or acquired diseases which appears during "critical periods" that may be described as restricted phases of cerebral maturity which must coincide with the occurrence of certain experiences for more rapid and effortless language acquisition. On the other hand, when exposure to these experiences does not coincide, it will be more difficult to occur these acquisitions during other phases of development (Klein and Rapin, 2002).

Craniofacial anomalies form an important group of congenital defects due to high morbidity, high prevalence in the population and important interference in the overall development of an affected individual (Amaral, 1997; Cohen et al., 1997, Gollop,1997).

Our society is organized for a human being with important organs (hands, eyes, ears) and certain cerebral functions. Typically, all instruments, techniques, signs and symbols are made according this type of human being, without any biological privations or any other organic alterations. The organs of speech, vision and hearing that participate intensely in our communication with the environment are situated in the face. The face reflects an individual's emotional and health status as well as character. Morphological facial alterations affect the most visible part of the body and can affect speech and mimicry (Gollop, 1997).

Language development can occur despite severe organic deficiencies and be similar to that 
of normal children regarding linguistic functioning. Nonetheless, emotional, organic and even environmental factors related to craniosynostosis may significantly interfere in the quality of this language. Another factor that usually affects language acquisition in craniosynostosis are hearing problems such as those of the middle ear, very common in this population (Zeisel and Roberts, 2003).

Otitis media is one of the main organic acquired conditions is very common in cases of craniofacial anomalies and is characterized by inflammation of the middle ear with the presence of a liquid that may be purulent. This interferes in the conduction of sound waves up to the entrance of the inner ear (Klein and Rapin, 2002; Zeisel and Roberts, 2003). Besides affecting the perception of speech segments, the inconstant hearing may affect understanding (voice intonation, emphasis and pitch) and can retard the concept of participation in a conversation (Klein and Rapin, 2002).

Children with syndromic craniosynostosis are at a higher risk for delayed language development due to frequent oititis wich may cause mild to moderate hearing loss (Rajenderkumar et al., 2005).

Although this group of congenital defects occurs frequently, a large number of the current studies are on anatomic, surgical, molecular and genetic aspects. The first results of a recently initiated longitudinal study of psychological aspects are quite homogeneous (Gil-da-SilvaLopes, 2004). On the other hand, phonoaudiological aspects related to language, audiological profile and oral motricity are still not totally characterized.

Besides the lack of language skill in general, children with craniofacial anomalies present difficulties regarding socialization. However, the origin of cognitive difficulties presented by those patients and their relation with primary malformation are still obscure (Ceponiene et al., 2001). The authors also indicate that hearing memory is fundamental for language learning and that this function is altered in such clinical conditions. On the other hand, Scheuerle et al. (2001) argue that early surgery of cranial sutures and therapeutic stimulation may reduce the impact of these learning difficulties and would contribute to satisfactory levels of development when compared with other children of the same age range.

The main craniosynostosis syndromes are presented below in the chronological order of clinical dicription as well as their related language aspects.

\section{Apert Syndrome}

It was first described by Wheaton in 1894 and denominated Acrocephalossyndactylias. In 1906, Apert conducted a systematic study of nine cases and defined its characteristics. Gorlin et al. (1995) conducted a study on the clinical characteristics of the Apert Syndrome and reported that the most common manifestations besides craniosynostosis were mid-facial malformations, deviation of the nasal septum and others like hypertelorism, strabismus, low set asymmetrical ears as well as ogival palate with a deep median sulcus, soft palate fissure or bifid uvula and nasopharyngeal alterations that reduced dimensions.

Obstruction of the airways is a frequent complication in this craniosynostosis. It is common during the first years of life and seems to be related to bad functioning of the hearing tube (Zeisel and Roberts, 2003). Compromised middle ear bone such as congenital fixation of the stapes bone and other anomalies of the auricular pavilion may result in conduction deafness in this group of individuals (Trevor, 1991). There are indications that hearing conduction deficiency is an important interfering factor in verbal communication (Jung, 1989; Tewfik and Der Kaloustian, 1997; Nord, 1999).

Children who present with the Apert Syndrome are at a higher risk for otitis media with effusion or accompanied by a moderate degree of fluctuating hearing loss (Rajederkumar et al., 2005). In this clinical condition, the palatine fissure may also be present (Gonzales et al., 1986).

Very little information is available on language development; however, case studies suggest that language alterations are directly related to cognitive level, hearing acuity and age at surgical interventions regarding craniofacial problems (Jung, 1989; Tewfik and Der Kaloustian, 1997; Nord, 1999; Da Costa et al., 2005).

Shipster et al. (2002) described the results of a pilot study on speech and language skills as well as other cognitive functions in ten individuals with the Apert Syndrome. Nine of these individuals presented abnormal voice and eight individuals demonstrated moderate or severe language alterations, the most common being difficulties regarding expression without cognitive deficit. All the individuals presented problems related to attention, speech and oro-motor skills. 
Crouzon Syndrome

This syndrome was first described in 1912 and was named after the physician who observed the condition. Problems resulting from bone arch anomalies often occur in this clinical condition causing alterations in respiration, feeding, vision, hearing and the central nervous system. The main complications involve moderate palatine dysfunction and hearing deficiency that usually occurs in about $50 \%$ of the cases, generally of the conductive type.

A study conducted by Orvidas et al. (1999) to establish the incidence and types of otological and audiologic anomalies in this syndrome verified that eight of the nineteen cases presented with anomalies of the external ear such as atresia of the external auditory canal, ten presented with hearing loss, of which four were conductive, two mixed losses and the remaining four neurosensorial hearing loss with diverse etiologies that ranged from fixation of the ossicular chain and otitis serosa to unknown sensorial deficits. Besides the hearing problems that interfered in language development, other complications may occur in these cases secondary to palatine fissure (Tewfik and Der Kaloustian, 1997; CSN, 1998; Nord, 1999).

\section{Pfeiffer Syndrome}

In 1964, Pfeiffer described this syndrome that is characterized by expressive heterogeneity of its clinical as well as molecular aspects. The craniofacial manifestations include flattened nasal tip, maxillary hypoplasia with relative prognathism, ogival palate, highly arched palate and visual disorders (Cohen, 1986).

This syndrome is classified into three types (Type1, Type 2 and Type 3 ) according to the clinical characteristics: Type 1-mild cranial and facial deformation and normal intelligence. Type 2 presents cloverleaf skull, severe ocular proptosis, more pronounced malformation of the limbs and compromised intellect. Type 3 presents practically the same characteristics as type 2 but a more severe form. Type 2 and 3 present an increased risk for early death due to frequent life threatening seizures and hydrocephalus (Cohen, 1993).

There are very few findings regarding the frequency of audiological alterations in this syndrome and some also refer to fixation of the ossicular chain that results in conductive hearing loss (Cremers, 1981).
Misquiatti (1996) studied language aspects related to emission and reception as well as developmental processes in a sample of 15 individuals, seven males and eight females, whose ages ranged from two years to 24 years (eight with the Apert Syndrome, four with Cruzon syndrome and three with Pfeiffer syndrome). Conductive hearing loss that varied between moderate and mild was also verified in nine individuals.

Regarding language aspects, it was observed that almost half of the studied population $(46,66 \%)$ presented delayed acquisition. The authors concluded that this delay was more related to hearing loss than to cognitive alterations due to the fact that despite the poor intellectual level presented, none of the individuals presented with mental deficiency.

\section{Saethre-Chotzen Syndrome}

The Saethre-Chotzen syndrome was described by two physicians Haakon Saethre (1931) and F. Chotzen (1932). It is characterized by several levels of cranial anomalies. The main facial characteristics are: low-set hairline, facial asymmetry, maxillary hypoplasia, mandibular prognathism and small lowset, dysmorphic ears (Howard et al., 1997). The nose may present a deviated septum, low or prominent bridge and in the oral region - ogival palate and dental anomalies (lack of supernumeraries or anomalous teeth) that result in bad occlusion (Reardon and Winter, 1994). The speech-hearing information on this condition is rare, especially since this is a condition difficult to diagnose (Gil-da- Silva-Lopes, 2004). Ensink et al. (1996) conducted a study on the Saethre-Chotzen syndrome and verified the presence of conductive hearing loss that in this case was relayed to ankyolosis of the stapes and fixation of the ossicular chain as well as chronic infections of the middle ear.

Arduino-Meirelles performed studies in ten affected individuals with age ranging from two to forty four years. In this individuals were observed problems in oral and hearing functions, independently of ages. The most comum alterations is orofacial movement and voice. The authors indicates a precocious phonoaudiological evaluation, and a clinical accompaniment. 


\section{Conclusion}

Clinical heterogeneity of craniosynostosis syndromes that include morphological and functional aspects as well as etiological and molecular regulatory mechanisms are still under investigation. Studies on genotype-phenotype correlations in a large number of cases may contribute towards individual follow up and better understanding of the genesis of this group of congenital defects.

Craniosynostosis hampers the natural process of oral language acquisition and development because it affects oro-facial structures responsible for speech, damages the hearing system, interferes in the psychological and physiologic development of the affected individual and hampers social development of the child. Therefore, early evaluation and follow up is indispensable. This procedure results in adequate diagnosis and treatment, avoiding hearing loss in many cases. However, when this condition goes undetected, it leads to sensory deprivation that affects the development of speech, language and cognitive skills.

\section{References}

ALONSO, L. G. Estudo genético-clínico das craniostenoses isoladas e associadas. 1997. 168 f. Tese (Mestrado em Morfologia) - Escola Paulista de Medicina, Universidade Federal de São Paulo, São Paulo.

ALTMANN, E. B. C.; VAZ, A. C. N.; PAUlA, M. B. S. F.; KHOURY, R. B. F. Tratamento Precoce. In: ALTMANN, E. B. C. Fissuras Labiopalatinas. 4. ed. Carapicuiba (SP): Pró-Fono, 1997. cap. 21, p. 312-314.

AMARAL, V. L. A. R. Aspectos psicossociais. In: ALTMANN, E. B. C. Fissuras Labiopalatinas. 4. ed. Carapicuiba (SP): Pró-Fono, 1997. cap. 30, p. 501-512.

ANDRADE, C. R. F. Prevalência das desordens idiopáticas da fala e da linguagem em crianças de um a onze anos de idade. R. Saúde Públ., São Paulov. 31, n. 5, p. 495501, out. 1997.

APERT, E. De l'acrocéphalosyndactylie. Bull Soc. Méd. Paris, v. 23, p. 1310-1330, 1906. Appud: MISQUIATTI, A. R. N. Avaliação de linguagem em indivíduos com síndrome de Apert, Crouzon e Pfeiffer. 1996. $103 \mathrm{f}$. Dissertação (Mestrado em Distúrbios da Comunicação) Faculdade de Fonoaudiologia, Pontifícia Universidade Católica de São Paulo, São Paulo.

ARDUINO-MEIRELLES, A. P. Aspectos fonoaudiológicos da síndrome de Saethre-Chotzen. 2006. 169 f. Dissertação (Mestrado em Saúde da Criança e do Adolescente) Faculdade de Ciências Médicas, Universidade Estadual de Campinas, Campinas.
BELLUS, G. A.; GAUDEZ, K.; ZACKAI, E. H.; CLARKE, L. A.; SZABO, J.; FRANCOMANO, C. A.; MUENKE, M. Identical mutations in three different fibrobast growth factor receptor genes in autosomal cranyosinostosis syndrome. Nat. Genet., United States, v. 2, n. 14, p. 174-176, oct. 1996.

CAPUTTE, A. J.; ACCARDO, P. J. Language assessment. In: CAPUTTE, A. J.; ACCARDO, P. J. (Ed.). Developmental and disabilities in infancy and chilhood. Baltimore: Paul H Brookes Publishing Co., 1991. p. 165-179.

CASTAÑO, J. Bases neurobiológicas Del lenguaje y sus alteraciones. R. Neurol., Barcelona, v. 36, n. 8, p. 781785, abr. 2003.

CEPONIENE, R.; HUKKI, J.; BALAN, P.; NÄÄTÄNEN, R. Central auditory dysfunction in children with craneofacial anomalies. In: INTERNATIONAL CONGRESS ON CLEFT PALATE AND RELATED CRANIOFACIAL ANOMALIES, 9., 2001, Göteborg. Resumos...Göteborg Sweden: Elanders Novum, 2001. p. 67.

CERVERA, M. J. F.; YGUAL, F. A. Intervención logopédica em los transtornos fonológicos desde el paradigma psicolingüístico del procesamiento del habla $R$. Neurol., Barcelona, v. 36, supl. 1, p. 39-53, fev. 2003.

COHEN, M. M. JR.; MACLEAN, R. E. Craniosynostosis: diagnosis, evaluation and manegement. New York: Oxford University Press, 2000.

COHEN, M. M. JR. Pfeiffer syndrome update, clinical subtypes, and guidelines for differential diagnosis. Am. J. Med. Genet., United States, v. 45, n. 3, p. 300-307, fev. 1993. 
COHEN, M. M. JR. Craniosynostosis: diagnosis, evaluation, and management. New York: Raven Press, 1986.

COHEN, M. M. JR.; GORLIN, R. J.; FRASER, F. C. Craniofacial disorders. In: RIMOIN, D. L.; CONNOR, J. M.; PYERITZ, R. E. Emery and Rimoin's principles and practice of medical genetics. 3. ed. New York: Churchill Livingston, 1997. v. Tomo III, p. 1121-1148.

CHOTZEN, F. Eine eigenartige familiäre En twicklungsstörung: Akrocephalosyndaktylie, dysostosis craniofacialis und hypertelorismus. Mschr Kinderheilk, v. 55 , p. $97-122,1932$.

CREMERS, C. W. R. J. Hearing loss in Pfeiffer's syndrome. Int. J. Pediatr. Otorhinolaryngol., Ireland, v. 3, n. 4, p. 343-353, dez. 1981

CROUZON, O. Dysostose cranio-faciale heréditaire. Bull Soc. Med. Hosp. Paris, v. 33, p. 545-555, 1912. Appud: MISQUIATTI, A. R. N. Avaliação de linguagem em indivíduos com síndrome de Apert, Crouzon e Pfeiffer. 1996. 103 f. Dissertação (Mestrado em Distúrbios da Comunicação) - Faculdade de Fonoaudiologia, Pontifícia Universidade Católica de São Paulo, São Paulo.

CSN Crouzon Support Network. Crouzon syndrome information. Disponível em http://www.crouzon.org/ crouzon.html. 1998.

DA COSTA, A. C.; SAVARIRAYAN, R.; WRENNALL, J. A.; WALTERS, I.; GARDINER, N.; TUCKER, A.; ANDERSON, V.; MEARA, J. G. Neuropsychological diversity in Apert syndrome: a comparision of cognitive profiles. Ann. Plast. Surg., United States, v. 54, n. 4, p. 450-455, abr. 2005

ENSINK, R. J.; MARRES, H. A.; BRUNNER, H. G.; CREMERS, C. W. Hearing loss in the Saethre-Chotzen syndrome. J. Laryngol. Otol., England, v. 110, n. 10, p. 952-957, oct. 1996.

GIL-DA-SILVA-LOPES, V. L. Atenção genético-clínica a portadores de anomalias craniofaciais. 2004. $287 \mathrm{f}$. Tese (Livre Docência em Genética-Clínica) - Faculdade de Ciências Médicas, Universidade Estadual de Campinas, Campinas.

GOLLOP, T. R. Genética Craniofacial. In: ALTMANN, E. B. C. Fissuras Labiopalatinas. 4. ed. Carapicuiba (SP): Pró-Fono, 1997. cap. 4, p. 39-47.

GONZALES, C. H.; KIM, C. A.; BRESOLINE, A. M. B.; PLESE, J. P. P. Caso em foco. Pediatr., São Paulo, v. 8, n. 2, p. 110-113, jun. 1986 .

GORLIN, R. J.; COHEN, M. M. JR.; LEVIN, L. S. Syndromes with craniosynostosis: general aspects and well-known syndromes. In:__. Syndromes of the head and neck. 3. ed. New York: Oxford University Press, 1990. p. 519-539.

GORLIN, R. J.; COHEN, M. M. JR.; LEVIN, L. S. Syndromes of abnormal craniofacial contour. In: Syndromes of the head and neck. 3. ed. New York: Oxford University Press, 1990. p. 563-586.

GORLIN, R. J.; COHEN, M. M. JR.; LEVIN, L. S. Branchial arch and oro-acral disorders. In:___. Syndromes of the head and neck. 3. ed. New York: Oxford University Press, 1990. p. 641-666.
GORLIN, R. J.; COHEN, M. M. JR.; LEVIN, L. S. Orofacial clefting syndromes: general aspects. In:_-_. Syndromes of the head and neck. 3. ed. New York: Oxford University Press, 1990. p. 693-714.

GORLIN, R. J.; TORIELLO, H. V.; COHEN, M. M. JR. Genetic hearing loss associated with musculoskeletal disorders: Hereditary hearing loss and its syndromes. New York: Oxford University Press, 1995.

HOWARD, T. D.; PAZNEKAS, W.; GREEN, E. D. Mutations in TWIST gene in the Saethre Chotzen syndrome. Nat. Genet., United States, v. 15, n. 1, p. 36-41, jan. 1997.

JUNG, J. H. Genetic syndromes in communication disorders. Boston, MA: College-Hill Press, 1989.

KAN, S. H.; ELANKO, N.; JOHNSON, D.; CORNEJOROLDAN, L.; COOK, J.; REICH, E. W.; TOMKINS, S.; VERLOES, A.; TWIGG, S. R.; RANNAN-ELIYA, S.; MCDONALD-MCGINN, D. M.; ZACKAI, E. H.; WALL, S. A.; MUENKE, M.; WILKIE, A. O. Genomic screening of fibroblast growth-factor receptor 2 reveals a wide spectrum of mutation in patients with syndromic craniosynostosis. Am. J. Hum. Genet., United States, v. 70, n. 2, p. 472-486, fev. 2002.

KLEIN, S. K; RAPIN, I. Perda intermitente da audição de condução e desenvolvimento da linguagem. In: BISHOP, D.; MOGFORD, K. Desenvolvimento da linguagem em circunstâncias excepcionais. Rio de Janeiro: Revinter, 2002. p. 123-144.

LUQUE, A.; VILA, I. Desarrollo del lenguaje. In: PALACIOS, J.; MARCHESI, A.; COLL, Y. (Comp.). Desarrollo psicológico y educación, t. I: Psicología evolutiva. Madrid: Alianza, 1995. p. 173-189.

LEE, S.; SETO, M.; SIE, K.; CUNNINGHAM, M. A child with Saethre-Chotzen syndrome, sensorioneural hearing loss, and a Twist mutation. Cleft Palate Craniofac. J., United States, v. 39, n. 1, p. 110-114, jan. 2002.

LARGO, M.; ZINI, T. C.; FERREIRA, V. J. A. A narrativa da criança e do adolescente na deficiência mental. $R$. Cons. Fed. Fonoaudiol., Brasília, v. 2, n. 3, p. 43, jun. 2003.

MISQUIATTI, A. R. N. Avaliação de linguagem em indivíduos com síndrome de Apert, Crouzon e Pfeiffer. 1996. 103 f. Dissertação (Mestrado em Distúrbios da Comunicação) - Faculdade de Fonoaudiologia, Pontifícia Universidade Católica de São Paulo, São Paulo.

MOGFORD, K.; BISHOP, D. Desenvolvimento da linguagem em condições normais. In: BISHOP, D.; MOGFORD, K. Desenvolvimento da linguagem em circunstâncias excepcionais. Rio de Janeiro: Revinter, 2002. p. 1-26.

NOGUEIRA, S.; FERNÁNDEZ, B.; PORFÍRIO, H.; BORGES, L. A criança com atraso na linguagem. Saúde Infant., Rio de Janeiro, v. 22, n. 1, p. 5-16, abr. 2000.

NORD - National Organization for Rare Disorders. Rare disease database. Danbury, 1999. Disponível em: <http:/ /www.rarediseases.org>. Acesso em: 21 abr. 2004.

OMIM (TM). Online Mendelian Inheritance in man (TM). Baltimore: Johns Hopkins University - MDMIM. 2005. n. \#101400. Disponível na Word Wide Web URL: <URL: http:/ /www.ncbi.nlm.nih.gov/omim/>. Acesso em: 15 mar. 2004. 
OMIM (TM). Online Mendelian Inheritance in man (TM). Baltimore: Johns Hopkins University - MDMIM. 2005. n. \#101200. Disponível na Word Wide Web URL: <URL: http:/ /www.ncbi.nlm.nih.gov/omim/>. Acesso em: 15 mar. 2004.

OMIM (TM). Online Mendelian Inheritance in man (TM). Baltimore: Johns Hopkins University - MDMIM. 2005. n. \#101600. Disponível na Word Wide Web URL: <URL: http:/ /www.ncbi.nlm.nih.gov/omim/>. Acesso em: 15 mar. 2004.

OMIM (TM). Online Mendelian Inheritance in man (TM). Baltimore: Johns Hopkins University - MDMIM. 2005. n. \#123500. Disponível na Word Wide Web URL: <URL: http:/ /www.ncbi.nlm.nih.gov/omim/>. Acesso em: 15 mar. 2004.

OPPERMAN, L. A. Cranial sutures as intramembranous bone growth sites. Dev. Dyn., United States, v. 219, n. 4, p. 472-475, dez. 2000 .

ORVIDAS, L. J.; FABRY, L. B.; DIACOVA, S.; MCDONALD, T. J. Hearing and Otopathology in Crouzon Syndrome. Laryngoscope, United States, v. 109, n. 9, p. 1372-1375, set. 1999.

PASSOS-BUENO, M. R.; WILCOX, W. R.; JABS, E. W.; SERTIE, A. L.; ALONSO, L. G.; KITOH, H. Clinical spectrum of fibroblast growth factor receptor mutations. Hum. Mutat., United States, v. 14, n. 2, p. 115-125, maio 1999.

PFEIFER, R. A. Dominant rebliche akrocephalosyndaktylie. Z. Kinderheilkd., v. 90, p. 301320, 1964. Appud: MISQUIATTI, A. R. N. Avaliação de linguagem em indivíduos com síndrome de Apert, Crouzon e Pfeiffer. 1996. 103 f. Dissertação (Mestrado em Distúrbios da Comunicação) - Faculdade de Fonoaudiologia, Pontifícia Universidade Católica de São Paulo, São Paulo.

RAJENDERKURMAR, D.; BAMIOU, D.; SIRIMANNA, T. Management of hearing loss in Apert syndrome. $J$. Laryngol. Otol., England, v. 119, n. 5, p. 385-390, maio 2005.

RAJENDERKURMAR, D.; BAMIOU, D.; SIRIMANNA, T. Audiological profile in Apert syndrome. Arch Dis. Child, England, v. 90, n. 6, p. 592-593, jun. 2005.

REARDON, W.; WILKES, D.; RUTLAND, P.; PULLEYN, L. J.; MALCOLM, S.; DEAN, J. C.; EVANS, R. D.; JONES, B. M.; HAYWARD, R.; HALL, C. M.; NEVIN, N. C.; BARAISTER, M.; WINTER, R. M. Craniosynostosis associated with FGFR3 pro250arg mutation results in a range of clinical presentations including unisutural sporadic craniosynostosis. J. Med. Genet., United States, v. 34, n. 8. p. 632-636, aug. 1997.
REARDON, W.; WINTER, R. M. Saethre-Chotzen syndrome. J. Med. Genet., United States, v. 31, n. 5, p. 393-396, maio 1994

RICE, D. P.; ABERG, T. et al. Integration of FGF and TWIST in calvarial bone and suture development. Development, England, v. 127, n. 9, p. 1845-1855, maio 2000 .

ROBIN, N. H. Molecular genetic advances in understanding craniosynostosis. Plastic Reconstr. Surg., United States, v. 103, n. 3, p. 1060-1070, mar. 1999.

SAETHRE, H. Ein Bietrag zum Turmschädelproblem: Pathogenese, erblichkeit und symptomatologie. Dtsch Z. Nervenheik, v. 119, p. 533-555, 1931.

SCHEUERLE, J.; GUILFORD, A. M.; HABAL, M. A longitudinal study of 33 patients with isolated craniosynostosis. In: INTERNATIONAL CONGRESS ON CLEFT PALATE AND RELATED CRANIOFACIAL ANOMALIES, 9., 2001, Göteborg. Resumos... Göteborg Sweden: Elanders Novum, 2001. p. 67.

SCHIRMER, C. R; FONTOURA, D. R.; NUNES, M. R. Distúrbios da aquisição da linguagem e da aprendizagem. $J$. Pediatr., Rio de Janeiro, v. 80, supl. 2, p. S95-103, abr. 2004.

SHIPSTER, C.; HEARST, D.; DOCKREL, J. E.; KILBY, E.; HAYWARD, R. Speech and language skills and cognitive functioning in children with Apert syndrome: a pilot study. Int. J. Lang. Commun. Disord., England, v. 37, n. 3, p. 325-343, jul. 2002.

TEWFIK, T. L.; KALOUSTIAN, V. M. Congenital anomalies of the ear, nose and throat. New York: Oxford University Press, 1997.

TREVOR, M. Otolaryngologic aspects of Apert syndrome. Clin. Plast. Surg., United States, v. 18, n. 2, p. 309-313, abr. 1991.

WHEATON, S. W. Two specimens of congenital cranial deformity in infantis associated with fusion of fingers and toe. Trans. Pathol. Soc., v. 45, p. 283-241, 1894.

WILKIE, A. Craniosynostosis: genes and mechanisms. Hum. Mol. Genet., England, v. 10, n. 6, p. 1647-1656, set. 1997.

ZEISEL, S. A.; ROBERTS, J. E. Otitis media in young children with disabilities. Infant. Young Child., v. 16, p. 106-119, 2003.

ZORZI, J.L. Problemas de desenvolvimento e aquisição da linguagem. In: Psicopedagogia on-line. Setembro/ 2003. Disponível em: www.psicopedagogia.com.br/entrevistas. Acesso em: 20 maio 2004. 